\title{
Evaluation of Industrial Training Effectiveness in Improving Self-Development Skills of Urban and Regional Planning Students
}

\author{
Intan Afida \\ Department of Geomatics and Built Environment, School of Professional and Continuing Education, \\ UTMSPACE, Kuala Lumpur, Malaysia \\ E-mail: afida@utmspace.edu.my
}

\begin{abstract}
The purpose of this study is to evaluate the effectiveness of industrial training in improving self-development skills, namely knowledge, work, and personal skills of urban and regional planning students. This study is important to help institutions of higher learning specifically and the industry generally understand how well IT can help students improve their self-development skills. A survey method was used in this study. The data were collected by using online questionnaires from 55 urban and regional planning final year students, with a response rate of 100 per cent. Data were analysed using descriptive statistics such as frequency, percentage, mean score, and inferential statistics, namely Wilcoxon Signed Rank Test. This study found that there were significant differences in the students' performance in knowledge, work, and personal skills from before and after industrial training. The study also found the detailed attributes for each skill improved by students after industrial training, namely 13 attributes for knowledge skills, 14 attributes for work skills, and 23 attributes for personal skills. This study was based on the perception of urban and regional planning students at one of the public universities in Malaysia. Being the first study to investigate the detailed attributes of three categories of self-development skills, improved in urban and regional planning students after industrial training that are specifically related to urban and regional planning, it contributes to the very limited research literature on the topic in the world generally and Malaysia specifically. Keywords: Industrial training, Effectiveness, Knowledge skills, Personal skills, Self-development skills, Work skills
\end{abstract}

DOI: $10.7176 / \mathrm{JEP} / 13-3-02$

Publication date: January $31^{\text {st }} 2022$

\section{Introduction}

The mismatch between skills acquired by students throughout their higher education with the demands and the needs of the industry is not new around the world (Abidoye et al. 2022; Dubey et al. 2021; Fernandez-Chung et al. 2015; Lowden et al. 2011). Prior researches suggested that the quality of graduates produced by institutions of higher learning (IHL) does not meet the needs of the industry (Azmi et al. 2018; Kagaari 2007). The changing and competitive conditions of the job market requires the industry to hire graduates who possess a complete skills package, not only in terms of knowledge but also soft skills (Rodzalan \& Saat 2012; Yaakob et al. 2018). Bennett (2002) suggested that graduates should also adapt to any changes that occur in the organisation. Apart from that, graduates also need to adapt themselves according to any changes in their respective fields. The adaptation skills will ensure graduates remain relevant and up-to-date with developments in their respective fields. The industry selects graduates who can perform well immediately upon acceptance to work in the organisation (Ayarkwa et al. 2012; Cox \& King 2006). In addition, the industry selects graduates who are independent, able to make decisions quickly and accurately in a short time, and able to work with minimal supervision.

The competitive job market in Malaysia in the 4th industrial revolution demanded that students not only need to have excellent academic qualifications but also soft skills. In response to that, Malaysia has taken proactive steps by introducing ten shifts in the Malaysia Education Blueprint 2015-2025 (Higher Education). One of those shifts was related to the development of holistic, entrepreneurial, and balanced graduates. As the world becomes more challenging, graduates need to prepare themselves with various soft skills such as communication, problemsolving, critical and creative thinking, leadership, teamworking, scholarship, adaptability, and enterprising. It will directly allow them to compete in their respective fields in the future more effectively.

Emphasis on embedding experiential learning into the curriculum has been stated in Shift 1: Initiative A1 Malaysia Education Blueprint 2015-2025 (Higher Education). Experiential learning is also known as learning through experience, and industrial training (IT) is one form of experiential learning (Christou \& Chatzigeorgiou 2019). Most of the undergraduate programs offered at an IHL in Malaysia have offered IT courses conducted for at least two months. Students are awarded certain academic credits for their IT. In general, students need to fill in the IT logbook, prepare IT reports, and make presentations at the end of IT to the IHL to be assessed. Students are also assessed by IHL-appointed supervisors and their supervisors in the organisation.

IT is experiential learning that is guided because the course learning outcomes and duration needs to be fulfilled by students have been determined by IHL before students go for IT. The provision of IT scope of work to students and industries is important to help them know the coverage and the level of task complexity that needs to 
be fulfilled to ensure the learning outcomes set by IHL are achieved after completing the IT. The diversity of the IT scope of work help students learn and sharpen their knowledge and soft skills.

\subsection{Problem Statement}

IT is one of the compulsory courses that students take once during their studies in all IHL in Malaysia that offers urban and regional planning programme. IT gives students the experience to use knowledge learned in the lecture room and studio to solve real-world problems. Each IHL outlines a range of learning outcomes to ensure students get the most out of the IT they undergo. The knowledge and experience gained throughout IT make students more competitive and marketable (Ayarkwa et al. 2012; Connor \& Shaw 2008; Lu 2021).

In general, three categories of self-development skills need to be mastered by students throughout their studies in IHL, namely knowledge, work, and personal skills (Shoenfelt et al. 2013; Woon et al. 2011). These three skills are important in developing a student who is balanced in mind and personality and has a high degree of adaptation to any changes and challenges. Enhancement of these skills can be done through IT courses undertaken by the students.

There are many studies to find out the effectiveness of IT to students in various fields such as accounting (Warinda, 2013), business (Anjum 2020), construction (Ayarkwa et al. 2012), engineering (Renganathan et al. 2012), information technology (Jones et al. 2017), textiles (Karunaratne \& Perera 2019), and tourism and hospitality (Subbiah et al. 2017).

However, studies on the effectiveness of IT in improving students' self-development skills, namely knowledge, work, and personal skills, especially for urban and regional planning students have not received significant attention from academic scholars. The detailed attributes of the skills that have been improved by these students that are specifically related to urban and regional planning (URP) also have not been explored.

\subsection{Significance of the study}

This study was to evaluate the extent to which IT has improved urban and regional planning students' selfdevelopment skills in terms of knowledge, work, and personal skills. The results of this study provide an opportunity for any IHL that offered urban and regional planning programme to understand the benefits of IT in terms of improving students' self-development skills. The IHLs could improve their current IT syllabus to foster more positive learning and outcomes among students or start planning to incorporate IT in their programme structure. This study also indirectly helps the industries to understand their role in honing the potential of students' self-development skills as best as possible throughout IT.

\section{Literature review}

\subsection{The benefits of IT}

IT enables students to test how much of their existing knowledge and skills can be used in a working environment while learning new knowledge and skills. IT allows students to acquire additional skills and experiences that they cannot acquire directly from the lecture rooms (Azmi et al. 2018; Renganathan et al. 2012). Through IT, students get real work experience in their respective fields (Kapareliotis et al. 2019; McManus \& Feinstein 2008). Yusof et al. (2013) suggested that IT also strengthen the relationship between IHL and industry. Subbiah et al. (2017) and Mengistu and Mahesh (2019) pointed out this relationship directly provide an opportunity for IHL to design a more industry-relevant and up-to-date curriculum for their programmes.

\subsection{Skills gained and improved throughout IT}

Students improve their general knowledge or specialised knowledge in the field and soft skills throughout IT (Maclean \& Ordonez 2007). Students practice the theory learned in IHL in the professional working environment and learn through colleagues in the organisation. In this way, students sharpen their existing skills and at the same time learn new skills.

Previous studies have proven that IT is a very effective platform for improving students' skills to enhance their marketability when they graduate (Anjum 2020; Kapareliotis et al. 2019). IT has also succeeded in giving students added value in career opportunities and self-qualification (Narayanan et al. 2010). Table 1 below shows the skills gained and improved by the students throughout IT from the previous studies. There are differences and similarities of skills between each study according to the needs of each study. Although many studies have been conducted, there are still no studies that examine the detailed attributes of the skills improved by students after IT that are directly related to any field. 
Table 1: Skills gained and improved by students after IT

\begin{tabular}{|c|c|c|}
\hline Author (Year) & Aspect & Criteria \\
\hline \multirow{20}{*}{$\begin{array}{l}\text { Ayarkwa et al. } \\
(2012)\end{array}$} & \multirow[t]{20}{*}{-} & Independence \\
\hline & & Ability to make decisions \\
\hline & & Ability to express ideas (oral and written) \\
\hline & & Non-verbal communication skills \\
\hline & & Ability to communicate with publics \\
\hline & & Negotiation skill \\
\hline & & Listening skill \\
\hline & & Ability to interact \\
\hline & & Ability to extract information \\
\hline & & Lifelong learning \\
\hline & & Disciplined and motivated \\
\hline & & Environmental awareness \\
\hline & & Social and multi-racial awareness \\
\hline & & Professionalism and work ethics \\
\hline & & Ability to carry out instructions \\
\hline & & Ability to function as a leader \\
\hline & & Ability to function as a team player \\
\hline & & Ability to apply knowledge \\
\hline & & Adequate background knowledge \\
\hline & & Seriousness towards work \\
\hline \multirow{24}{*}{$\begin{array}{l}\text { Subbiah et al. } \\
\text { (2017) }\end{array}$} & \multirow[t]{24}{*}{-} & Oral communication \\
\hline & & Practical skills \\
\hline & & Industry knowledge \\
\hline & & Customer service skills \\
\hline & & Adoptability to work \\
\hline & & Self-confidence \\
\hline & & Time management \\
\hline & & Teamworking skills \\
\hline & & Interpersonal skills \\
\hline & & Written communication \\
\hline & & Work ethics \\
\hline & & Organisational ability \\
\hline & & Critical thinking \\
\hline & & Attention to detail \\
\hline & & Management skills \\
\hline & & Leadership skills \\
\hline & & Problem solving skills \\
\hline & & Creativity \\
\hline & & Marketing and sales skills \\
\hline & & Event management skills \\
\hline & & Legal understanding \\
\hline & & Decision making \\
\hline & & Research skills \\
\hline & & Negotiation skills \\
\hline \multirow{13}{*}{$\begin{array}{l}\text { Kapareliotis et al. } \\
\text { (2019) }\end{array}$} & \multirow{11}{*}{$\begin{array}{l}\text { Basic academic/ } \\
\text { technical skills }\end{array}$} & Communication in writing \\
\hline & & Verbal communication \\
\hline & & Communicating through technology \\
\hline & & Presenting to an audience \\
\hline & & Working as a team member \\
\hline & & Collaboration to complete group tasks \\
\hline & & Gets along with others \\
\hline & & Work with people from diverse origins \\
\hline & & Using quantitative tools \\
\hline & & Analysing data \\
\hline & & Using technology \\
\hline & \multirow{2}{*}{$\begin{array}{l}\text { High order thinking } \\
\text { skills }\end{array}$} & Identify problems \\
\hline & & Creative and innovative thinking \\
\hline
\end{tabular}




\begin{tabular}{|c|c|c|}
\hline \multirow{29}{*}{$\begin{array}{l}\text { Anjum } \\
(2020)\end{array}$} & \multirow{7}{*}{ Professional skills } & Make appropriate decisions \\
\hline & & Timely decisions \\
\hline & & Complete the task on time \\
\hline & & Complete the task without supervision \\
\hline & & Coping with uncertainty \\
\hline & & Working under pressure \\
\hline & & Accepting responsibility \\
\hline & \multirow{5}{*}{$\begin{array}{l}\text { Professional } \\
\text { development }\end{array}$} & Changed students' professionally \\
\hline & & Made clear students' career goals \\
\hline & & Application of classroom knowledge \\
\hline & & $\begin{array}{l}\text { Help students gain practical work experience in their } \\
\text { field of interest }\end{array}$ \\
\hline & & $\begin{array}{l}\text { Help students to identify the skills needed to get a job } \\
\text { in their field of interest }\end{array}$ \\
\hline & \multirow[t]{6}{*}{ Professional skills } & $\begin{array}{l}\text { Improved communication and interpersonal team } \\
\text { skills }\end{array}$ \\
\hline & & Enhanced decision making and problem solving skills \\
\hline & & Improved teamworking skills \\
\hline & & Enhance critical thinking \\
\hline & & Improve computer skills \\
\hline & & Improve in technical field \\
\hline & \multirow[t]{5}{*}{ Personal growth } & Mature professionally and personally \\
\hline & & Changed personal career goals \\
\hline & & $\begin{array}{l}\text { Developed a habit to accomplish task before the set } \\
\text { target after internship }\end{array}$ \\
\hline & & Improved classroom concepts \\
\hline & & Changed personal aspirations in some ways \\
\hline & \multirow[t]{6}{*}{ Personal capabilities } & Improved conscientiousness and ethics \\
\hline & & $\begin{array}{l}\text { Polished habit to have a respect for people different } \\
\text { from themselves }\end{array}$ \\
\hline & & Taught how to learn \\
\hline & & Improved skills to manage time and money \\
\hline & & Improved social relationships \\
\hline & & Enhanced initiative taking \\
\hline
\end{tabular}

A study by Ayarkwa et al. (2012) showed that the top five skills improved by students after IT were the ability to carry out instructions, teamwork, ability to apply knowledge, listening skill, and seriousness towards work. The study conducted by Subbiah et al. (2017) has discovered that the top five skills that were improved significantly by students after IT were oral communication, practical skills, industry knowledge, customer service skills, and adaptability to work.

In another study, Kapareliotis et al. (2019) found that the top five skills that were improved significantly by students after IT were working as a team member, getting along with others, communicating through technology, using technology, and working under pressure. A study by Anjum (2020) showed that the top five skills that were improved significantly by students after IT were enhanced initiative-taking, developed a habit to accomplish the task before the set target, changed personal aspirations in some ways, changed their interest in accounting and finance, and improved social relations.

\section{Research methodology}

\subsection{Survey instrument}

This study utilised a structured questionnaire prepared by the researcher in a Google Form. The objectives of the study, declaration of the intended use of the information given in the questionnaire, explanation of the questionnaire parts, and the estimated time duration to complete the questionnaire were provided to the students.

There were two parts in the questionnaire, namely Part A and Part B. 2 questions in Part A were about the students' background and 51 questions in Part B were about the students' performance before and after IT in terms of self-development skills.

Part A consisted of close-ended questions, which were multiple-choice questions. Part B consisted of closeended questions which were Likert scale questions using 5 points where $1=$ very poor; $2=$ poor; $3=$ fair; $4=$ good; and $5=$ very good. Open-ended questions were also used in Part B to enhance the researcher's understanding of the answers given by students for the Likert scale questions.

Cronbach's Alpha values were calculated to determine the reliability of the questions and measurements for 
all Likert scale questions. Alpha values obtained for the three self-development skills ranged from 0.78 to 0.87 , which is considered acceptable to good (George \& Mallery 2016). These indicate that the questions provided reliably measure the three self-development skills consistently.

\subsection{Data collection}

The data for this study were collected through an online survey. This online survey was carried out for two days. This survey was conducted anonymously to increase students' confidence to answer all questions honestly. The survey response rate was 100 per cent.

\subsection{Samples}

This study was conducted on all 55 final year students of urban and regional planning programme at one of the public universities in Malaysia. Students had completed their IT for four months (16 weeks) at urban planning government agencies and urban planning firms nationwide. The scope of work that needed to be fulfilled by students throughout the IT prepared by the IHL had been given to all organisations involved in supervising students' IT.

\subsection{Data analysis}

Data were analysed using IBM SPSS Statistics version 26. Descriptive statistics, namely frequency, percentage, mean score, and inferential statistics, namely Wilcoxon Signed Rank Test were used in this study. Effect sizes were calculated to measure how much did IT improve students' self-development skills.

\section{Results and discussion}

4.1 Students' backgrounds involved in this study

The findings revealed that 58.2 per cent were female students and 41.8 per cent were male students. The data showed that out of 32 female students, 71.9 per cent of them had undergone IT at urban planning firms and the other 28.1 per cent at local planning authorities. Out of 23 male students, 73.9 per cent had undergone IT at urban planning firms, 21.7 per cent at local planning authorities, and 4.3 per cent at federal planning authorities, as shown in Table 2.

Table 2: IT placement according to gender

\begin{tabular}{lcccc}
\hline & Urban planning firm & \multicolumn{2}{c}{ IT placement } & Tocal planning \\
Gender & & authority & $\begin{array}{c}\text { Federal planning } \\
\text { authority }\end{array}$ & Total \\
\hline Female & $23(71.9 \%)$ & $9(28.1 \%)$ & $0(0.0 \%)$ & $32(58.2 \%)$ \\
Male & $17(73.9 \%)$ & $5(21.7 \%)$ & $1(4.3 \%)$ & $23(41.8 \%)$ \\
Total & $40(72.7 \%)$ & $14(25.5 \%)$ & $1(1.8 \%)$ & $55(100.0 \%)$ \\
Note: $n=55$ & & & & \\
\hline
\end{tabular}

\subsection{Students' performance before IT for knowledge, work, and personal skills}

The knowledge, work, and personal skills obtained mean scores of more than 3.00 before IT. Most students give a score of 3, which was fair for the assessed criteria. Some students gave a score of 4 , which was good, and a score of 5 , which was very good for the assessed criteria.

For knowledge skills, awareness of the needs for lifelong learning was the criterion with the highest mean score for male and female students with 3.52 and 3.88, respectively. The ability to solve technical problems was the criterion with the lowest mean score for male students with 3.04, and ability to apply knowledge was the criterion with the lowest mean score for female students with 3.19 (refer Table 3). 
Table 3: Students' performance before and after IT for knowledge, work, and personal skills

\begin{tabular}{|c|c|c|c|c|}
\hline \multirow[t]{2}{*}{ Skills } & \multicolumn{2}{|c|}{$\begin{array}{c}\text { Male } \\
\text { Mean score }(\mathrm{SD})\end{array}$} & \multicolumn{2}{|c|}{$\begin{array}{c}\text { Female } \\
\text { Mean score (SD) }\end{array}$} \\
\hline & Before IT & After IT & Before IT & After IT \\
\hline \multicolumn{5}{|l|}{ Knowledge skills } \\
\hline Ability to apply knowledge & $\begin{array}{c}3.22 \\
(0.951)\end{array}$ & $\begin{array}{c}4.17 \\
(0.717)\end{array}$ & $\begin{array}{c}3.19 \\
(0.780)\end{array}$ & $\begin{array}{c}4.19 \\
(0.471)\end{array}$ \\
\hline Ability to acquire new knowledge & $\begin{array}{c}3.48 \\
(0.898)\end{array}$ & $\begin{array}{c}4.26 \\
(0.752)\end{array}$ & $\begin{array}{c}3.50 \\
(0.762)\end{array}$ & $\begin{array}{c}4.50 \\
(0.622)\end{array}$ \\
\hline $\begin{array}{l}\text { Ability to solve technical } \\
\text { problems }\end{array}$ & $\begin{array}{c}3.04 \\
(1.022)\end{array}$ & $\begin{array}{c}4.22 \\
(0.951)\end{array}$ & $\begin{array}{c}3.25 \\
(0.803)\end{array}$ & $\begin{array}{c}4.13 \\
(0.609)\end{array}$ \\
\hline $\begin{array}{l}\text { Awareness of the needs for } \\
\text { lifelong learning }\end{array}$ & $\begin{array}{c}3.52 \\
(1.238)\end{array}$ & $\begin{array}{c}4.65 \\
(0.573)\end{array}$ & $\begin{array}{c}3.88 \\
(0.833)\end{array}$ & $\begin{array}{c}4.56 \\
(0.619)\end{array}$ \\
\hline \multicolumn{5}{|l|}{ Work skills } \\
\hline Verbal communication & $\begin{array}{c}3.61 \\
(0.783)\end{array}$ & $\begin{array}{c}4.52 \\
(0.665)\end{array}$ & $\begin{array}{c}3.34 \\
(0.653)\end{array}$ & $\begin{array}{c}4.22 \\
(0.608)\end{array}$ \\
\hline Writing & $\begin{array}{c}3.26 \\
(1.096)\end{array}$ & $\begin{array}{c}4.35 \\
(0.982)\end{array}$ & $\begin{array}{c}3.41 \\
(0.756)\end{array}$ & $\begin{array}{c}4.13 \\
(0.609)\end{array}$ \\
\hline Delivery of ideas & $\begin{array}{c}3.48 \\
(0.947)\end{array}$ & $\begin{array}{c}4.52 \\
(0.730)\end{array}$ & $\begin{array}{c}3.34 \\
(0.745)\end{array}$ & $\begin{array}{c}4.00 \\
(0.718)\end{array}$ \\
\hline Discussion & $\begin{array}{c}3.17 \\
(0.984)\end{array}$ & $\begin{array}{c}4.43 \\
(0.662)\end{array}$ & $\begin{array}{c}3.38 \\
(0.660)\end{array}$ & $\begin{array}{c}4.16 \\
(0.628)\end{array}$ \\
\hline Listening and responding & $\begin{array}{c}3.43 \\
(1.037)\end{array}$ & $\begin{array}{c}4.74 \\
(0.541)\end{array}$ & $\begin{array}{c}3.59 \\
(0.756)\end{array}$ & $\begin{array}{c}4.38 \\
(0.660)\end{array}$ \\
\hline Decision-making & $\begin{array}{c}3.30 \\
(0.876)\end{array}$ & $\begin{array}{c}4.39 \\
(0.656)\end{array}$ & $\begin{array}{c}3.41 \\
(0.798)\end{array}$ & $\begin{array}{c}4.13 \\
(0.609)\end{array}$ \\
\hline \multicolumn{5}{|l|}{ Personal skills } \\
\hline Self-confidence & $\begin{array}{c}3.43 \\
(0.992)\end{array}$ & $\begin{array}{c}4.39 \\
(0.656)\end{array}$ & $\begin{array}{c}3.25 \\
(0.916)\end{array}$ & $\begin{array}{c}4.41 \\
(0.615)\end{array}$ \\
\hline Time management & $\begin{array}{c}3.17 \\
(0.984)\end{array}$ & $\begin{array}{c}4.43 \\
(0.590)\end{array}$ & $\begin{array}{c}3.59 \\
(0.946)\end{array}$ & $\begin{array}{c}4.38 \\
(0.609)\end{array}$ \\
\hline Curiosity & $\begin{array}{c}3.70 \\
(0.876)\end{array}$ & $\begin{array}{c}4.74 \\
(0.449)\end{array}$ & $\begin{array}{c}3.84 \\
(0.884)\end{array}$ & $\begin{array}{c}4.72 \\
(0.457)\end{array}$ \\
\hline Independence & $\begin{array}{c}3.65 \\
(0.832)\end{array}$ & $\begin{array}{c}4.35 \\
(0.647)\end{array}$ & $\begin{array}{c}3.69 \\
(0.931)\end{array}$ & $\begin{array}{c}4.31 \\
(0.644)\end{array}$ \\
\hline Punctuality & $\begin{array}{c}3.65 \\
(0.885)\end{array}$ & $\begin{array}{c}4.39 \\
(0.583)\end{array}$ & $\begin{array}{c}3.84 \\
(0.987)\end{array}$ & $\begin{array}{c}4.56 \\
(0.504)\end{array}$ \\
\hline Teamwork & $\begin{array}{c}3.78 \\
(0.850)\end{array}$ & $\begin{array}{c}4.61 \\
(0.449)\end{array}$ & $\begin{array}{c}3.97 \\
(0.782)\end{array}$ & $\begin{array}{c}4.56 \\
(0.619)\end{array}$ \\
\hline Work under pressure & $\begin{array}{c}3.48 \\
(1.039)\end{array}$ & $\begin{array}{c}4.57 \\
(0.507)\end{array}$ & $\begin{array}{c}3.69 \\
(0.965)\end{array}$ & $\begin{array}{c}4.19 \\
(0.780)\end{array}$ \\
\hline
\end{tabular}

Note: $n=55$

High mean scores were obtained by female students in three knowledge skills criteria, namely ability to acquire new knowledge, ability to solve technical problems, and awareness of the needs for lifelong learning. The only high mean score obtained by male students for knowledge skills was the ability to apply knowledge (refer Figure 1). 


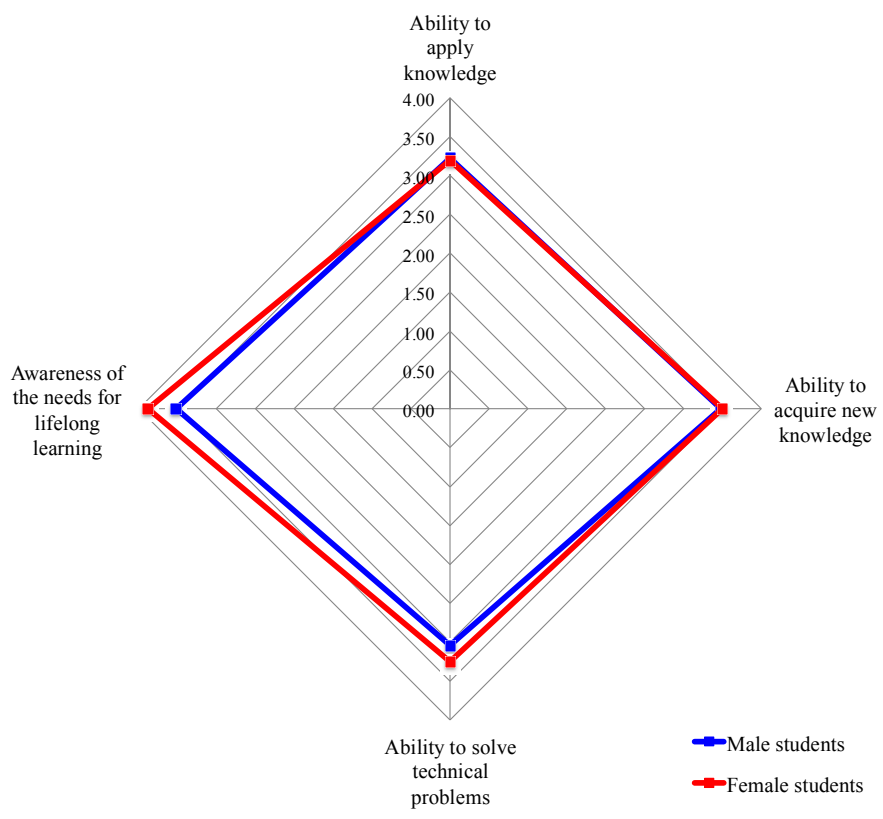

Figure 1: Knowledge skills, comparing male and female students before IT

For work skills, verbal communication was the criterion with the highest mean score of 3.61, while the discussion was the criterion with the lowest mean score of 3.17 for male students. The listening and responding was the criterion with the highest mean score of 3.59, while the verbal communication and the delivery of ideas were the criteria with the lowest mean score of 3.34 each for female students (refer Table 3 ).

High mean scores were obtained by female students in four work skills criteria, namely writing, discussion, listening and responding, and decision-making. High mean scores were obtained by male students in two more criteria, namely verbal communication and delivery of ideas (refer Figure 2).

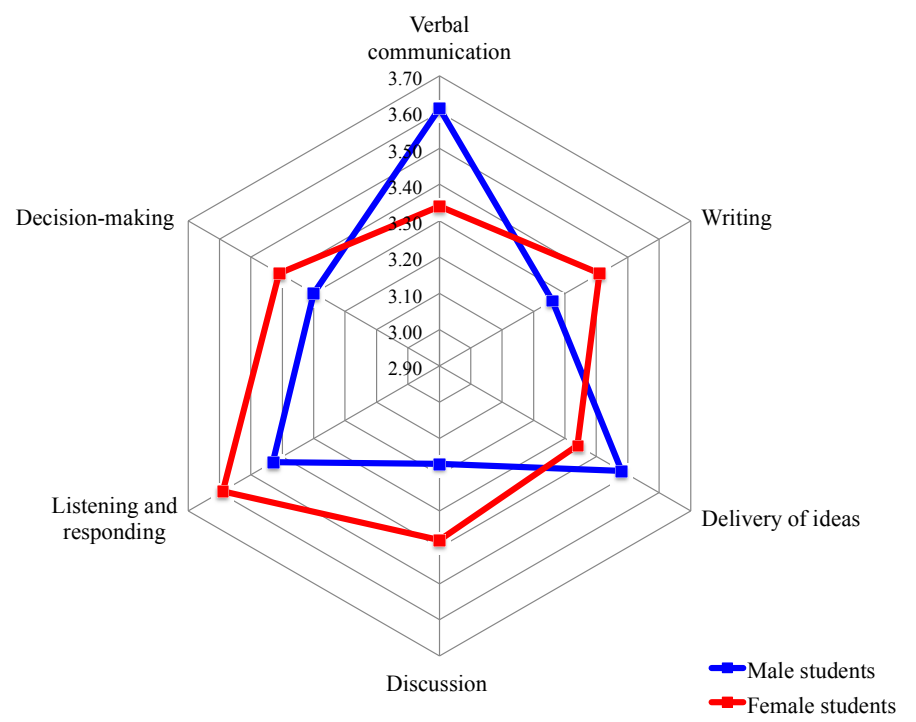

Figure 2: Work skills, comparing male and female students before IT

For personal skills, teamwork was the criterion with the highest mean scores for male and female students with 3.78 and 3.97, respectively. Time management was the criterion with the lowest mean score for male students with 3.17 and self-confidence was the criterion with the lowest mean score for female students with 3.25 (refer Table 3).

High mean scores were obtained by female students in six personal skills criteria, namely time management, curiosity, independence, punctuality, teamwork, and work under pressure. The only high mean score obtained by male students for personal skills was self-confidence (refer Figure 3). 


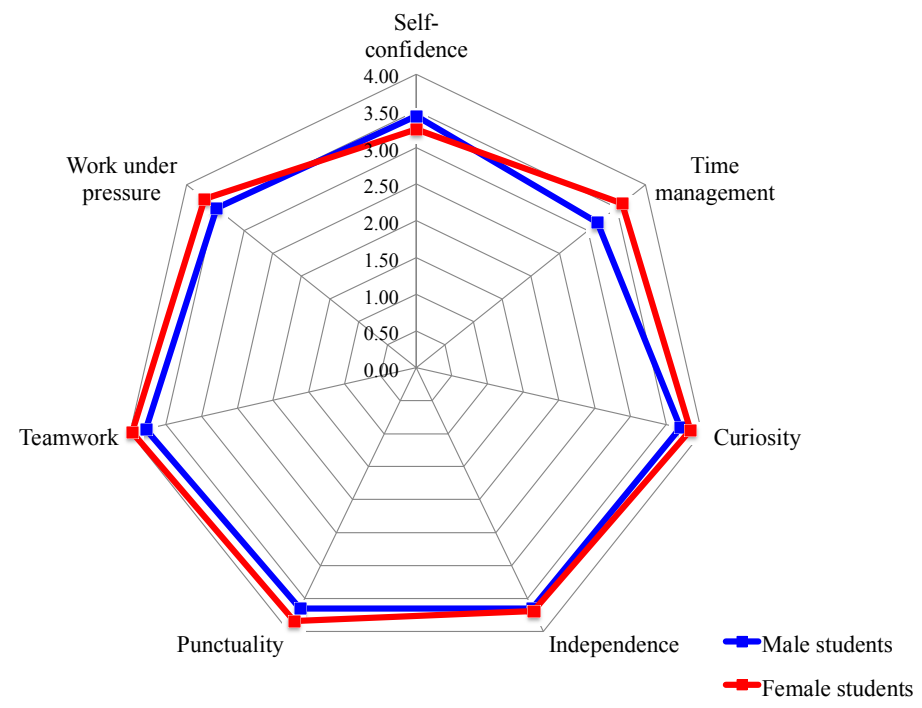

Figure 3: Personal skills, comparing male and female students before IT

The above results confirmed the findings in the literature review that IT is required as an effective platform to help enhance knowledge and skills acquired by students at IHL to make them more competitive and marketable when they graduate (Anjum 2020; Ayarkwa et al. 2012; Kapareliotis et al. 2019; Lu 2021; Yaakob et al. 2018). Through IT, knowledge, work, and personal skills is improved to ensure balanced and holistic students can be developed by IHL (Ayarkwa et al. 2012; Shoenfelt et al. 2013; Woon et al. 2011). In addition, knowledge and skills related to the respective fields are learned directly from the industries (Kapareliotis et al. 2019; McManus \& Feinstein 2008; Renganathan et al. 2012).

\subsection{Students' performance after IT for knowledge, work, and personal skills}

The knowledge, work, and personal skills have obtained mean scores of either 4.00 or more than 4.00 after IT. These indicate that there were improvements in terms of scores given by all students for all criteria after they underwent IT.

For knowledge skills, awareness of the needs for lifelong learning was the criterion with the highest mean score for male and female students with 4.65 and 4.56, respectively. The ability to apply knowledge was the criterion with the lowest mean score for male students with 4.17 and ability to solve technical problems was the criterion with the lowest mean score for female students with 4.13 (refer Table 3).

High mean scores were obtained by female students in two knowledge skills criteria, namely ability to apply knowledge and ability to acquire new knowledge. High mean scores were obtained by male students in two more criteria, namely ability to solve technical problems and awareness of the needs for lifelong learning (refer Figure $4)$. 


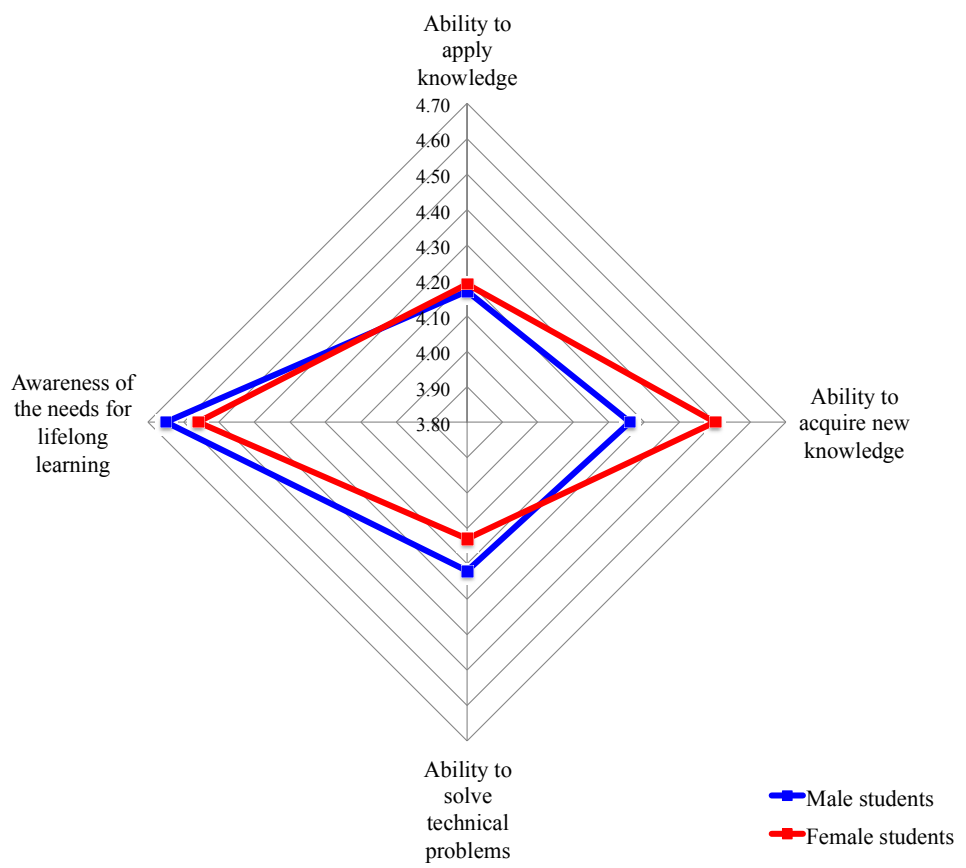

Figure 4: Knowledge skills, comparing male and female students after IT

For work skills, listening and responding had the highest mean score with 4.74 for male students and 4.38 for female students. Writing was the criterion with the lowest mean score for male students with 4.35 and delivery of ideas was the criterion with the lowest mean score for female students with 4.00 (refer Table 3 ).

High mean scores were obtained by female students in all six work skills criteria, namely verbal communication, writing, delivery of ideas, discussion, listening and responding, and decision-making (refer Figure $5)$.

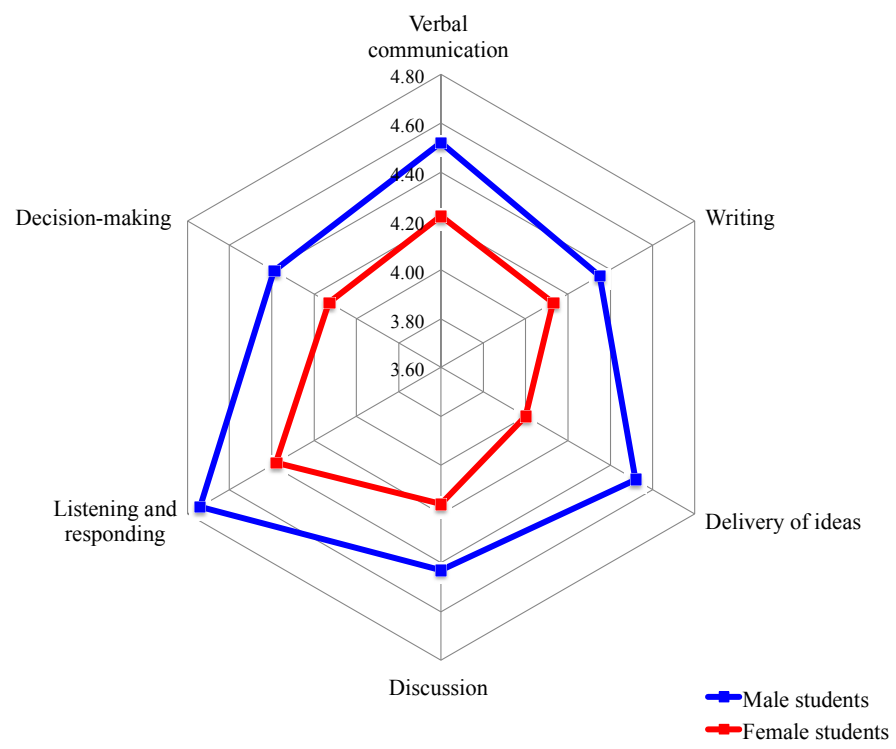

Figure 5: Work skills, comparing male and female students after IT

For personal skills, curiosity was the criterion with the highest mean score for male and female students with 4.74 and 4.72, respectively. Independence was the criterion with the lowest mean score for male students with 4.35 and work under pressure was the criterion with the lowest mean score for female students with 4.19 (refer Table $3)$.

High mean scores were obtained by male students in five personal skills criteria, namely time management, curiosity, independence, teamwork, and work under pressure. High mean scores were obtained by female students in two more criteria, namely self-confidence and punctuality (refer Figure 6). 


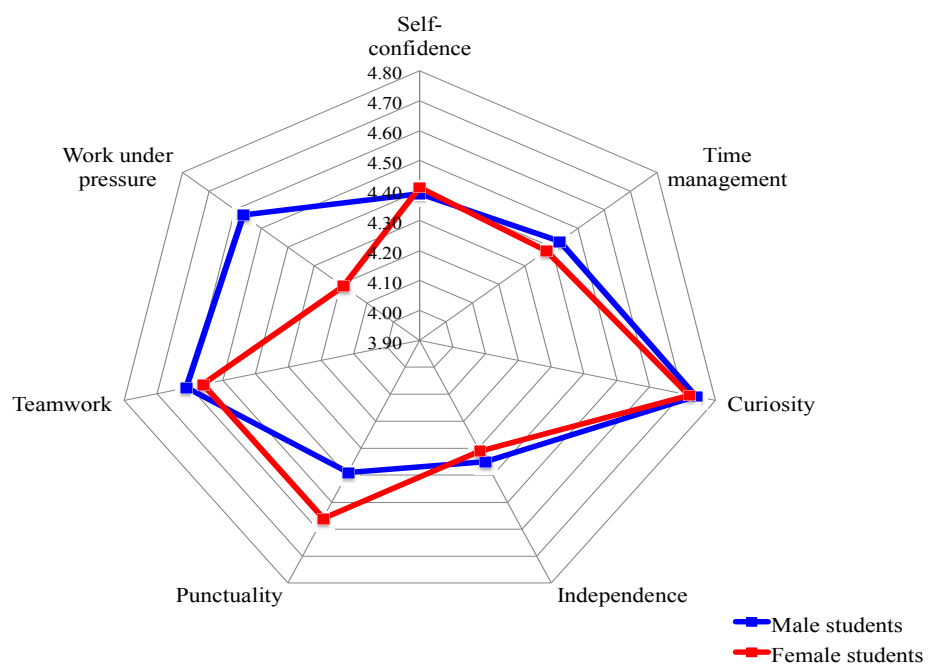

Figure 6: Personal skills, comparing male and female students after IT

The above results were in line with the findings from Anjum (2020), Ayarkwa et al. (2012), Kapareliotis et al. (2019), and Subbiah et al. (2017). There were improvements to the knowledge and soft skills of the students after they underwent IT. Through IT, students were exposed to various scopes of work in their respective fields (Kapareliotis et al. 2019; McManus \& Feinstein 2008). Through the diversity of the work, students learn and further improve the application of existing and new knowledge and soft skills through co-operation and interaction with people from inside and outside the organisation.

4.4 Significant difference in students' performance for knowledge, work, and personal skills from before and after IT

Wilcoxon Signed-Rank Test revealed significant differences in performance before and after IT for all three categories of self-development skills, namely knowledge, work, and personal skills. These indicate that all students experienced improvements in all three skills assessed after IT. Z-values, significant values, and effect sizes for the knowledge, work, and personal skills of male and female students are shown in Table 4. Effect size between 0.10 - 0.29 is classified as small effect size, while effect size between $0.30-0.49$ is classified as medium effect size (Cohen, 1988).

Table 4: Significant difference in students' performance for knowledge, work, and personal skills from before and after IT, comparing male and female students

\begin{tabular}{lcccc}
\hline & Male & & Female \\
Skills & Z-value (Sig.) & $r$ & Z-value (Sig.) & $r$ \\
\hline Knowledge skills & & & & \\
Ability to apply knowledge & $-3.345(0.001)$ & 0.32 & $-4.559(0.000)$ & 0.43 \\
Ability to acquire new knowledge & $-3.216(0.001)$ & 0.31 & $-4.344(0.000)$ & 0.41 \\
Ability to solve technical problems & $-3.469(0.001)$ & 0.33 & $-4.237(0.000)$ & 0.40 \\
Awareness of the needs for lifelong learning & $-3.531(0.000)$ & 0.34 & $-3.641(0.000)$ & 0.35 \\
Work skills & & & & \\
Verbal communication & $-3.666(0.000)$ & 0.35 & $-4.540(0.000)$ & 0.43 \\
Writing & $-3.345(0.001)$ & 0.32 & $-3.988(0.000)$ & 0.38 \\
Delivery of ideas & $-3.520(0.000)$ & 0.34 & $-3.892(0.000)$ & 0.37 \\
Discussion & $-3.573(0.000)$ & 0.34 & $-4.068(0.000)$ & 0.39 \\
Listening and responding & $-3.376(0.001)$ & 0.32 & $-3.929(0.000)$ & 0.37 \\
Decision-making & $-3.601(0.000)$ & 0.34 & $-4.413(0.000)$ & 0.42 \\
Personal skills & & & & \\
Self-confidence & $-3.531(0.000)$ & 0.34 & $-4.478(0.000)$ & 0.43 \\
Time management & $-3.804(0.000)$ & 0.36 & $-3.727(0.000)$ & 0.36 \\
Curiosity & $-3.619(0.000)$ & 0.35 & $-4.203(0.000)$ & 0.40 \\
Independence & $-2.859(0.004)$ & 0.27 & $-3.497(0.000)$ & 0.33 \\
Punctuality & $-3.153(0.002)$ & 0.30 & $-3.782(0.000)$ & 0.36 \\
Teamwork & $-3.578(0.000)$ & 0.34 & $-3.065(0.002)$ & 0.29 \\
Work under pressure & $-3.345(0.001)$ & 0.32 & $-2.876(0.004)$ & 0.27 \\
Note: $n=55 ; p<0.01$ & & & & \\
\hline
\end{tabular}


For male students, 14 out of 17 criteria obtained effect sizes lower than that obtained by female students for the same criteria. Time management had the highest effect size with 0.36 . Independence had the lowest effect size with 0.27 . Both criteria that have obtained the highest and lowest effect sizes were in the category of personal skills.

For female students, the ability to apply knowledge, verbal communication, and self-confidence had the highest effect sizes with 0.43 . These three criteria were in the category of knowledge, work, and personal skills. Work under pressure had the lowest effect size with 0.27 . This criterion was in the category of personal skills.

This study found that there were significant differences in students' performance from before and after IT with small to medium effect sizes. It proved that IT could further improve knowledge and soft skills as emphasised by Maclean and Ordonez (2007). These findings have further contributed to the literature in studies measuring the effectiveness of IT to students where the effect sizes have been calculated. Effect sizes were used to measure how much IT improved students' self-development skills. As emphasised by Kline (2004), the reporting of significant differences should be accompanied by the reporting of the effect sizes. This study not only focused on finding if IT did improve students' self-development skills but also how much did IT improve them.

\subsection{Attributes of knowledge, work, and personal skills improved by students after IT}

Students provided attributes of knowledge, work, and personal skills that have been successfully improved by them after IT. Students could provide more than one attribute for each criterion. The researcher had categorised the attributes given according to the relevant themes (refer Table 5, Table 6, and Table 7).

Table 5: Attributes of knowledge skills improved after IT

\begin{tabular}{|c|c|c|}
\hline Knowledge skills attributes & $f$ & $\%$ \\
\hline \multicolumn{3}{|l|}{ Ability to apply knowledge } \\
\hline Relate the knowledge learned at IHL in the context of URP practices & 48 & 87.3 \\
\hline Apply the knowledge learned at IHL for URP tasks & 32 & 58.2 \\
\hline $\begin{array}{l}\text { Understand the relationship between the knowledge learned at IHL to meet the } \\
\text { learning needs }\end{array}$ & 26 & 47.3 \\
\hline \multicolumn{3}{|l|}{ Ability to acquire new knowledge } \\
\hline Acquire new knowledge related to URP from various sources & 34 & 61.8 \\
\hline Acquire new knowledge unrelated to URP from various sources & 19 & 34.6 \\
\hline Acquire new knowledge through self-reading & 17 & 30.9 \\
\hline \multicolumn{3}{|l|}{ Ability to solve technical problems } \\
\hline Solve technical problems related to URP by using the knowledge (hands-on) & 40 & 72.7 \\
\hline Solve technical problems related to URP by using the knowledge (theories) & 21 & 38.2 \\
\hline Solve technical problems related to URP creatively & 8 & 14.5 \\
\hline \multicolumn{3}{|l|}{ Awareness of the needs for lifelong learning } \\
\hline $\begin{array}{l}\text { Always find opportunities to acquire new knowledge in URP from formal or } \\
\text { informal channels }\end{array}$ & 35 & 63.6 \\
\hline Always motivated to try various tasks related to URP & 29 & 52.7 \\
\hline Always motivated to build new skills & 17 & 30.9 \\
\hline Always motivated to keep learning every day & 12 & 21.8 \\
\hline Note: $n=55$; multiple response (students can give more than 1 answer) & & \\
\hline
\end{tabular}


Table 6: Attributes of work skills improved after IT

\begin{tabular}{|c|c|c|}
\hline Work skills attributes & $f$ & $\%$ \\
\hline \multicolumn{3}{|l|}{ Verbal communication } \\
\hline $\begin{array}{l}\text { Communication skills in terms of appropriate word selection, voice intonation and selection of } \\
\text { appropriate time to communicate }\end{array}$ & 38 & 69.1 \\
\hline Appropriate way to communicate in order to get accurate information & 33 & 60.0 \\
\hline Body language & 13 & 23.6 \\
\hline \multicolumn{3}{|l|}{ Writing } \\
\hline Technical reports either in Bahasa Melayu or English & 47 & 85.5 \\
\hline Formal letters and e-mails either in Bahasa Melayu or English & 25 & 45.5 \\
\hline Various forms either in the form of hard copy or soft copy & 14 & 25.5 \\
\hline \multicolumn{3}{|l|}{ Delivery of ideas } \\
\hline Communicate ideas related to URP & 52 & 94.5 \\
\hline Communicate ideas unrelated to URP & 10 & 18.2 \\
\hline \multicolumn{3}{|l|}{ Discussion } \\
\hline Active in discussions related to URP & 49 & 89.1 \\
\hline Active in discussions unrelated to URP & 25 & 45.5 \\
\hline \multicolumn{3}{|l|}{ Listening and responding } \\
\hline Listen to the instructions given by others & 51 & 92.7 \\
\hline Sensitive to the people around and give the necessary response accordingly & 26 & 47.3 \\
\hline \multicolumn{3}{|l|}{ Decision-making } \\
\hline Simple decisions related to URP tasks & 43 & 78.2 \\
\hline Daily / weekly / monthly decisions for himself or herself & 29 & 52.7 \\
\hline
\end{tabular}

Table 7: Attributes of personal skills improved after IT

\begin{tabular}{|c|c|c|}
\hline Personal skills attributes & $f$ & $\%$ \\
\hline \multicolumn{3}{|l|}{ Self-confidence } \\
\hline Confident in daily interactions especially with adults & 47 & 85.5 \\
\hline Confident in self-appearance & 42 & 76.4 \\
\hline Confident in making decisions for himself or herself & 25 & 45.5 \\
\hline Confident in making decisions for others & 13 & 23.6 \\
\hline \multicolumn{3}{|l|}{ Time management } \\
\hline Set time limit to complete URP tasks & 32 & 58.2 \\
\hline Organize URP tasks according to priorities & 29 & 52.7 \\
\hline Choose the right time to initiate discussion related to URP & 11 & 20.0 \\
\hline \multicolumn{3}{|l|}{ Curiosity } \\
\hline Understand the responsibilities of an urban planner & 53 & 96.4 \\
\hline Have a deeper interest in URP & 32 & 58.2 \\
\hline Ask about URP in general and URP tasks given in specific & 28 & 50.9 \\
\hline Open to explore various tasks in URP & 16 & 29.1 \\
\hline \multicolumn{3}{|l|}{ Independence } \\
\hline Remain disciplined even when no one is around & 36 & 65.5 \\
\hline Complete URP tasks with minimal supervision & 32 & 58.2 \\
\hline Give his or her opinion to complete the URP tasks & 22 & 40.0 \\
\hline \multicolumn{3}{|l|}{ Punctuality } \\
\hline Punctual in submitting URP tasks & 52 & 94.5 \\
\hline Punctual in terms of attendance to any meetings and discussions & 39 & 70.9 \\
\hline \multicolumn{3}{|l|}{ Teamwork } \\
\hline Responsible to complete URP tasks within the stipulated time & 48 & 87.3 \\
\hline Work cooperatively to complete URP tasks & 35 & 63.6 \\
\hline Accept constructive criticism from others & 26 & 47.3 \\
\hline Listen to others & 19 & 34.5 \\
\hline \multicolumn{3}{|l|}{ Work under pressure } \\
\hline Learn how to break down the URP tasks to make them easier to do & 37 & 67.3 \\
\hline Stay focused on the task at hand & 33 & 60.0 \\
\hline Make every task as an opportunity to learn new things & 15 & 27.3 \\
\hline
\end{tabular}


There were 13 attributes stated by students for knowledge skills (refer Table 5). The most stated attributes for each criterion are as follows. 87.3 per cent of students admitted they managed to relate more to the knowledge learned at IHL in the context of URP practices and 61.8 per cent of students stated they managed to acquire more new knowledge related to URP from various sources. Besides that, 72.7 per cent of students stated they managed to solve more real problems related to URP by using their knowledge (hands-on) and 63.6 per cent of students admitted they always found opportunities to acquire new knowledge in URP from formal or informal channels.

There were 14 attributes disclosed by students for work skills (refer Table 6). The most stated attributes for each criterion are as follows. 69.1 per cent of students stated they successfully improved verbal communication in terms of appropriate word selection, voice intonation, and selection of appropriate time to communicate, 85.5 per cent of students admitted they improved their skills on technical reports writing either in Bahasa Melayu or English and 94.5 per cent of students stated they improved their skills on how to communicate ideas related to URP. Besides that, 89.1 per cent of the students admitted they became more active in discussions related to URP, 92.7 per cent of the students stated they listened to the instructions given by others better, and 78.2 per cent of students claimed they managed to make simple decisions related to URP tasks.

There were 23 attributes stated by students for personal skills (refer Table 7). The most stated attributes for each criterion are as follows. 85.5 per cent of students revealed they improved their self-confidence in daily interactions especially with adults, 58.2 per cent of students admitted they managed to set time limit to complete URP tasks, 96.4 per cent of students said that they improved their understanding on the responsibilities of an urban planner, and 65.5 per cent of students stated that they managed to remain disciplined even when no one is around. Besides that, 94.5 per cent of students revealed they became more punctual in submitting URP tasks, 87.3 per cent of students stated they became more responsible to complete URP tasks within the stipulated time, and 67.3 per cent of students admitted they improved their skills on how to break down the URP tasks to make them easier to do.

The attributes of knowledge, work, and personal skills from this study further enrich the findings from previous researches (Anjum 2020, Ayarkwa et al. 2012, Kapareliotis et al. 2019, and Subbiah et al. 2017). There were 50 attributes of self-development skills that have been improved by students after IT.

\section{Conclusion}

This study evaluated the effectiveness of IT in improving self-development skills in detail, namely knowledge, work, and personal skills of urban and regional planning students in one of the public universities in Malaysia. The knowledge, work, and personal skills for male and female students have obtained mean scores of either 4.00 or more than 4.00 after IT. These indicate that there were improvements in terms of scores given by all students for all criteria after they underwent IT. Although significant differences in students' performance before and after IT only show small to medium effect sizes, IT has proven successful in improving all the criteria assessed for selfdevelopment skills in this study. Only three criteria in personal skills had a significant difference with small effect size, namely independence, work under pressure, and teamwork. There were 13 attributes for knowledge skills, 14 attributes for work skills, and 23 attributes for personal skills identified in this study. All the 50 attributes were directly related to URP. Besides that, findings from this study will assist any IHL that offered urban and regional planning programme to understand the benefits of IT in terms of improving students' self-development skills. This study also will assist URP organisations to understand their roles in improving students' self-development skills throughout IT. IT has been proven as an effective platform for students to develop and improve their selfdevelopment skills. Students can practice their knowledge and skills in URP in a professional working environment and learn directly from URP organisations. Students can prepare themselves to move into the world of higher education and employment with confidence.

\section{Recommendations for further research}

Below are some of the recommendations for further research:

(1) More studies should be conducted to evaluate the effectiveness of IT in improving self-development skills in detail for a different programme of study; and

(2) Other studies can adopt a different method of data collection such as in-depth interviews to get more insight on the self-development skills that have been improved after IT.

\section{References}

Abidoye, R., Lim, B. T. H., Lin. Y.C. \& Ma, J. (2022), Equipping property graduates for the digital age, Sustainability, 14, 640. https://doi.org/10.3390/su14020640

Anjum, S. (2020), Impact of internship programs on professional and personal development of business students: a case study from Pakistan, Future Business Journal, 6(1), 1-13. https://doi.org/10.1186/s43093-019-0007-3

Ayarkwa, J., Adinyira, E. \& Osei-Asibey, D. (2012), Industrial training of construction students: perceptions of training organizations in Ghana, Education+ Training, Vol. 54 No. 2/3, 234-249. 
https://doi.org/10.1108/00400911211210323

Azmi, A. N., Kamin, Y., Noordin, M. K. \& Nasir, A. N. M. (2018), Towards industrial revolution 4.0: employers' expectations on fresh engineering graduates, International Journal of Engineering \& Technology, 7(4.28), 267-272. https://doi.org/10.14419/ijet.v7i4.28.22593

Bennett, R. (2002), Employers' demands for personal transferable skills in graduates: a content analysis of 1000 job advertisements and an associated empirical study, Journal of Vocational Education and Training, 54(4), 457-476. https://doi.org/10.1080/13636820200200209

Christou, E. \& Chatzigeorgiou, C. (2019), Experiential learning through industrial placement in hospitality education: the meat in the sandwich, Journal of Contemporary Education Theory \& Research, 3(2), 31-35. https://doi.org/10.5281/zenodo.3635961

Cohen, J. (1988), Statistical Power Analysis for the Behavioral Sciences, Lawrence Erlbaum Associates Publishers, Hillsdale, NJ.

Connor, H. \& Shaw, S. (2008), Graduate training and development: current trends and issues, Education+ Training, Vol. 50 No. 5, 357-365. https://doi.org/10.1108/00400910810889048

Cox, S. \& King, D. (2006), Skill sets: an approach to embed employability in course design, Education + Training, Vol. 48 No. 4, 262-274. https://doi.org/10.1108/00400910610671933

Dubey, R. S., Paul, J. \& Tewari, V. (2021), The soft skills gap: a bottleneck in the talent supply in emerging economies, The International Journal of Human Resource Management, 1-32. https://doi.org/10.1080/09585192.2020.1871399

Fernandez-Chung, R. M., Ching, L. Y., Cheok, C. K. \& Hill, C. (2015), Employability of graduates in Malaysia: the perceptions of selected students and parents. https://www.britishcouncil.org/sites/default/files/phase_ii_employability_of_graduates_in_malaysia_studen t_parent_perceptio.pdf

George, D. \& Mallery, P. (2016), IBM SPSS Statistics 23 Step by Step, Routledge, NY.

Jones, F. R., Mardis, M. A., McClure, C. R., Ma, J., Ambavarapu, C. \& Spears, L.I. (2017), Work-integrated learning (WIL) in information technology: an exploration of employability skills gained from internships, Higher Education, Skills and Work-Based Learning, Vol. 7 No. 4, 394-407. https://doi.org/10.1108/HESWBL-08-2017-0046

Kagaari, J. R. (2007), Evaluation of the effects of vocational choice and practical training on students' employability, Journal of European Industrial Training, Vol. 31 No. 6, 449-471. https://doi.org/10.1108/03090590710772640

Kapareliotis, I., Voutsina, K. \& Patsiotis, A. (2019), Internship and employability prospects: assessing student's work readiness, Higher Education, Skills and Work-Based Learning, Vol. 9 No. 4, 538-549. https://doi.org/10.1108/HESWBL-08-2018-0086

Karunaratne, K. \& Perera, N. (2019), Students' perception on the effectiveness of industrial internship programme, Education Quarterly Reviews, Vol. 2 No. 4, 822-832. https://doi.org/10.31014/aior.1993.02.04.109

Kline, R. B. (2004), Beyond Significance Testing: Reforming Data Analysis Methods in Behavioral Research, American Psychological Association, Washington D. C.

Lowden, K., Hall, S., Elliot, D. \& Lewin, J. (2011), Employers' perceptions of the employability skills of new graduates. https://www.educationandemployers.org/wp-content/uploads/2014/06/ employability skills as pdf - final online version.pdf

Lu, H. F. (2021), Enhancing university student employability through practical experiential learning in the sport industry: An industry-academia cooperation case from Taiwan, Journal of Hospitality, Leisure, Sport \& Tourism Education, Vol. 28 (2021). https://doi.org/10.1016/j.jhlste.2021.100301

Maclean, R. \& Ordonez, V. (2007), Work, skills development for employability and education for sustainable development, Educational Research for Policy and Practice, 6(2), 123-140. https://doi.org/10.1007/s10671007-9017-y

Mengistu, D. G. \& Mahesh, G. (2019), Construction education in Ethiopia: Knowledge and skills level attained and effectiveness of internship program, Higher Education, Skills and Work-Based Learning, Vol. 9 No. 3 , 510-524. https://doi.org/10.1108/HESWBL-06-2018-0062

Ministry of Education Malaysia. (2015), Malaysia Education Blueprint 2015-2025 (Higher Education), Ministry of Education Malaysia, Putrajaya.

McManus, A. \& Feinstein, A. H. (2008), Internships and occupational socialization: what are students learning?, in Developments in Business Simulation and Experiential Learning: Proceedings of the Annual ABSEL Conference, Vol. 35, 128-137.

Narayanan, V. K., Olk, P. M. \& Fukami, C. V. (2010), Determinants of internship effectiveness: an exploratory model, Academy of Management Learning \& Education, 9(1), 61-80. https://doi.org/10.5465/AMBPP.2006.22898555

Renganathan, S., Karim, Z. A. B. A. \& Li, C. S. (2012), Students' perception of industrial internship programme, 
Education + Training, Vol. 54 No. 2/3, 180-191. https://doi.org/10.1108/00400911211210288

Rodzalan, S. A. \& Saat, M. M. (2012), The effects of industrial training on students' generic skills development, Procedia-Social and Behavioral Sciences, 56, 357-368. https://doi.org/10.1016/j.sbspro.2012.09.664

Shoenfelt, E. L., Stone, N. J. \& Kottke, J. L. (2013), Internships: an established mechanism for increasing employability, Industrial and Organizational Psychology, 6(1), 24-27. https://doi.org/10.1111/iops.12004

Subbiah, K., Kannan, S., Koiyu, R. \& Monama, L. (2017), Undergraduate students perception on industrial training, International Journal of Business and Management Invention, Vol. 6 Issue 7, 72-76.

Warinda, T. (2013), Accounting students' evaluation of internship experiences from a skills perspective, International Journal of Asian Social Science, 3(3), 783-799.

Woon, L. F., Karim, Z. A. A. \& Johl, S. K. (2011), Examining a successful industrial training program model: inter-relationship among the three main stakeholders: students, university and host companies, Review of Higher Education \& Self-Learning, 4(8), 16-26.

Yaakob, H., Ail, K. M. \& Radzi, N. F. (2018), The effect of internship on job performance: an assessment of students' perception, International Journal of Scientific \& Engineering Research, Vol. 9 Issue 7, 378-382. https://doi.org/10.13140/RG.2.2.13694.48966

Yusof, N. A., Fauzi, S. N. F. M., Abidin, N. Z. \& Awang, H. (2013), Improving graduates' employability skills through industrial training: suggestions from employers, Journal of Education and Practice, Vol. 4 No. 4, 23-29. 